\title{
FOSSIL TRACKS FROM VARVED SEDIMENTS NEAR LAMMI, SOUTH FINLAND
}

\author{
P. L. GIBBARD
}

\begin{abstract}
GIBBARD, P. L. 1977: Fossil tracks from varved sediments near Lammi, South Finland, Bull. Geol. Soc. Finland 49: 53-57.

A varved silty clay sequence at Harassilta is described and related to the Baltic history. Slump horizons are thought to have been formed during the fall in water level from BIII to YI. Trace fossils discovered in the varved clays are discussed and assigned to the activities of benthonic insect larvae.

P. L. Gibbard, Department of Geology, University of Oulu, SF-90100 Oulu 10, Finland.*

* Present address: Subdepartment of Quaternary Research, Botany School, Downing Street, Cambridge CB2 $3 E A$, England.
\end{abstract}

\section{Introduction}

Examination of a sequence of varved clays and silts led to the discovery of fossil animal tracks or trace fossils which have not previously been described from Finland. The tracks are discussed and related to the sequence found at the fossil locality.

\section{Stratigraphy}

A section at Harassilta on the boundary of Lammi and Koski communes (map no. 2133 $05, \mathrm{x}=675898, \mathrm{y}=55512$ ) where the ground surface is at $105 \mathrm{~m}$ O.D. (Fig. 1) exposes some $3.5 \mathrm{~m}$ of varved clay deposits (Fig. 2). Here the basal $2 \mathrm{~m}$ consist of well defined varves composed of alternating buff silt and dark brown silty clay couplets. They decrease in thickness upwards from over $35 \mathrm{~mm}$ to approximately $5 \mathrm{~mm}$. Resting on this horizon are two contorted bands each $15 \mathrm{~cm}$ thick composed of varved clay and silt exactly similar to that on which they rest. The lower band rests on the undisturbed varves beneath. However, the second band lies on a wellmarked eroded surface on the lower horizon. The bands show complex overfolding typical of that produced by slumping towards the direction $168^{\circ}$ (average of four readings). Immediately above the folded horizons are further narrow undisturbed varves $(3-5 \mathrm{~mm}$ thick), which become progressively thicker until at $15 \mathrm{~cm}$ above the contorted beds several sandy varves up to $15 \mathrm{~mm}$ in thickness occur. The sand laminae vary in thickness across the section. Overlying the sandy varves are further finely laminated brownish grey silty clays, with individual couplets between 1 and $5 \mathrm{~mm}$ thick. The laminae become progressively less distinct and more clayey 


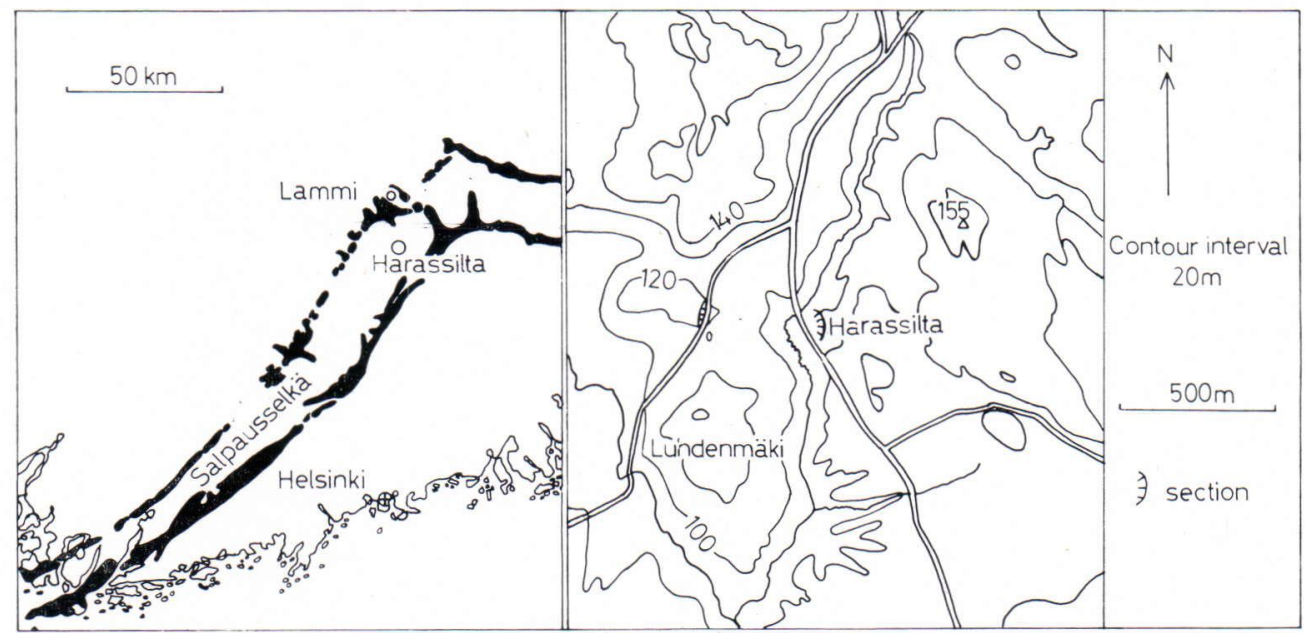

Fig. 1. Location map.

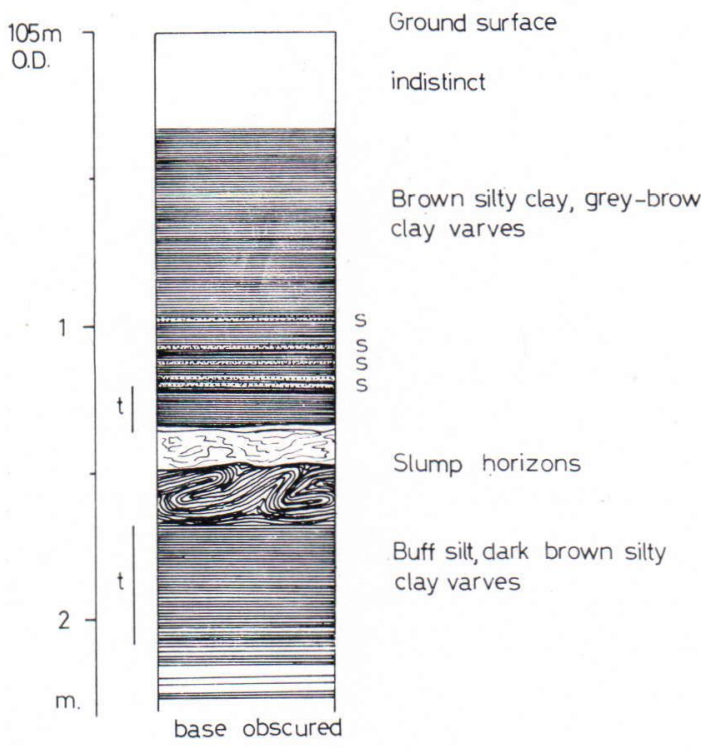

$t$ trace fossils

$s$ sand bands

PLG

Fig. 2. Summary diagram of the sequence at Harassilta in May 1976.

towards the top of the section. The stratigraphy is uniform over the whole exposure of some $20 \mathrm{~m}$. The trace fossils occur in the silty varves both in the $15 \mathrm{~cm}$ above and 30 cm below the slumped horizons, although they are most abundant in the latter.

Correlation of the varve sequence with that of Sauramo (1918) is shown in Fig. 3. According to Sauramo this place, which lies between the Salpausselkä moraines SsI and SsII, some $10 \mathrm{~km}$ south of the Second Salpausselkä, was deglaciated in approximately varve year -300 (about 10,500 B.P.). The surface of the Baltic Ice Lake at nearby Koski based on Sauramo's diagram initially stood at the BII level of $158 \mathrm{~m}$ then dropped to the BIII level of $153 \mathrm{~m}$ when the retreating ice reached the Second Salpausselkä (Sauramo 1958). Therefore, there was a water depth of $50 \mathrm{~m}$ at Harassilta. With the retreat of the ice from the Second Salpausselkä in varve year \pm 0 in Sauramo's chronology $(10,200$ B.P.), the water level dropped $28 \mathrm{~m}$ to the Yoldia YI level (Sauramo 1958, Donner 1969). This gives a water level, on the basis of Sauramo's diagram, of $125 \mathrm{~m}$ at the sample site and a depth of $20 \mathrm{~m}$. Such a drop in water level would have exposed the surrounding high ground, including the esker hills at Luhdenmäki immediately west and north-west of the site (Fig. 1). A section in a road cutting 

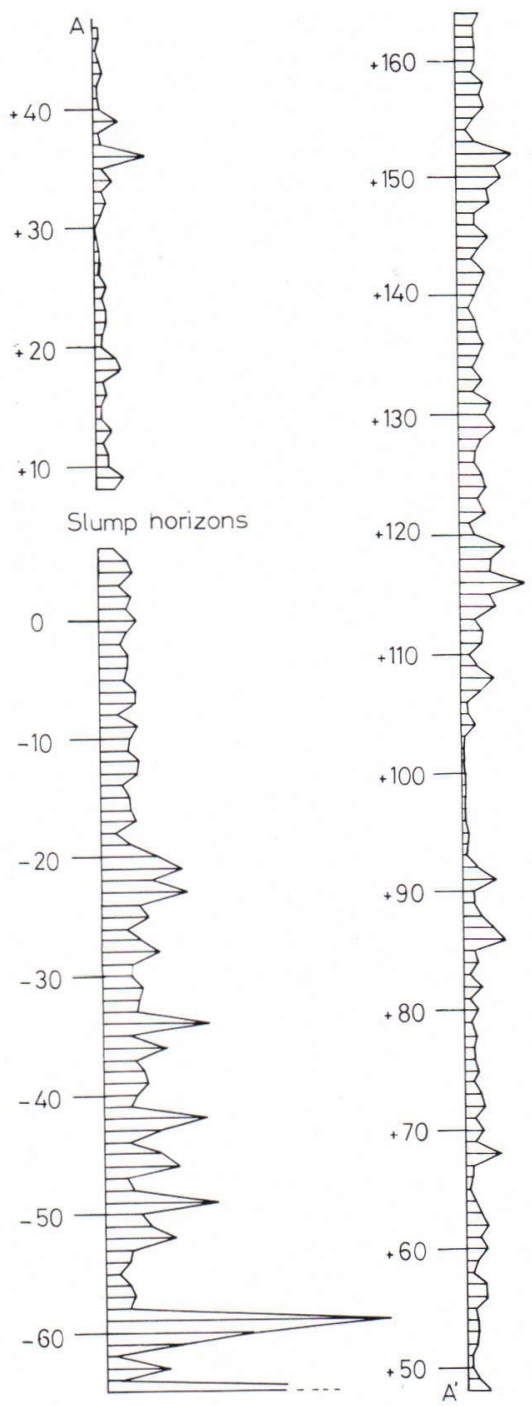

PLG

Fig. 3. The varve sequence at Harassilta showing the proposed correlations with Sauramo's (1918) varve chronology.

in these hills $(\mathrm{x}=675900, \mathrm{y}=55470)$, where the surface is at $127 \mathrm{~m}$ O.D., exposed varved clays similar to those at Harassilta resting in and restricted to a kettle-like hollow $4 \mathrm{~m}$ deep in the esker sands. It is likely that the varved clays originally covered the hills and that the drop in water level caused the slumping of sediment seen in the Harassilta section. The slumped horizons correspond to Sauramo's varve year +7 (Fig. 3) and if they do represent the drop to the YI level form a useful stratigraphical marker. The gradual retreat of the ice towards the north accounts for the diatactic varves becoming more clayey and uniform in thickness upwards. The water probably remained fresh for a period after the drainage of the Baltic Ice Lake owing to the close proximity of the ice front. The trace fossils occur in the sediments correlated with approximately -40 to +80 in Sauramo's chronology and therefore date from the latest part of the Weichselian (Younger Dryas) and earliest Flandrian (Donner 1971).

\section{Trace fossils}

The tracks were obtained by splitting the sediment, which breaks along the coarser silty
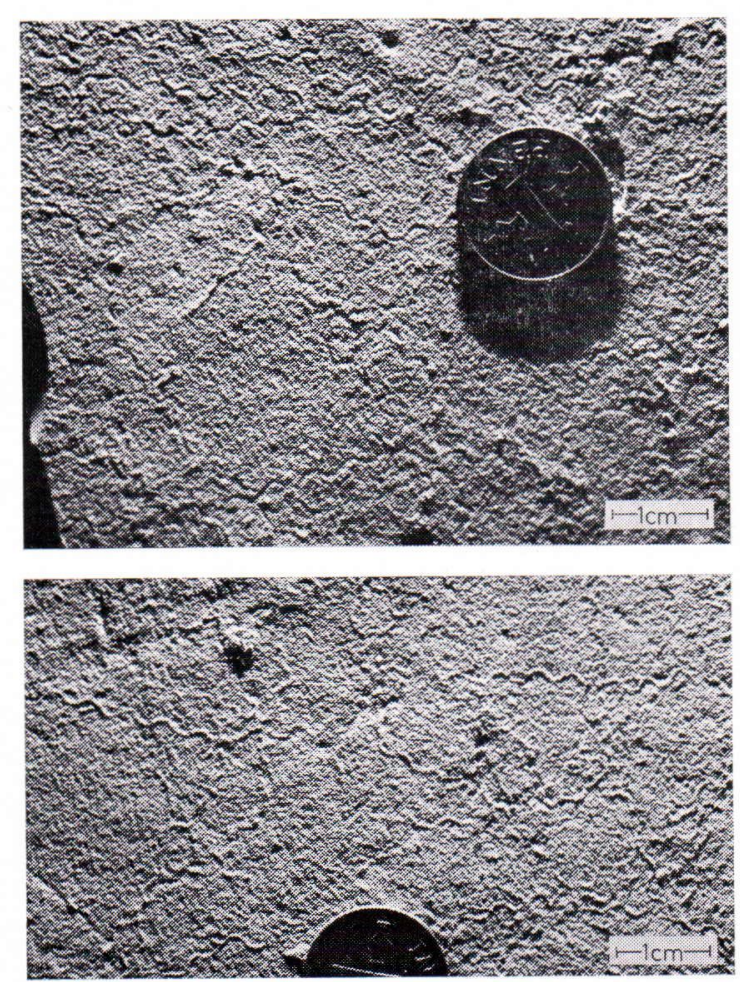

Fig. 4. (above) Insect larval tracks in varved silty clay at Harassilta. (below) Cast of the tracks from Harassilta. 
bedding planes presumably representing the spring and summer accumulation. The sediment contains very little organic material. The tracks discovered are shown in Fig. 4. Only one type was found and consists of small regular undulating trails $0.5 \mathrm{~mm}$ wide with a wavelength of $3 \mathrm{~mm}$. The tracks have no preferred orientation and vary in density. They are continuous, unbranched and can be traced across the same bedding plane for a considerable distance (over $60 \mathrm{~cm}$ in one instance). They occur as indentations in the sediment and can be distinguished from root markings and drying cracks by their regularity, restriction to single silt horizons and lack of oxidation aureoles. Although found in coarse silt to clayey silt sediments they are better preserved and more common in the latter. The tracks are exactly the same in size and shape as those described by Gibbard and Stuart (1974, type f) from Elsterian (Anglian) proglacial lake sediments in England. Identical undulating trails in varved grey silty clay sediments from Glacial Lake Champagne of late Wisconsinan age in Alaska were brought to the writers' notice by Dr H. Hyvärinen (Fig. 5).

Remarkably similar tracks were described by Andersson (1897) from Weichselian sediments in Sweden and he attributed them to chironomid midge larvae (Arthropoda, Insecta, Diptera). However, as Gibbard and Stuart pointed out, these larvae live in tubes bored into the sediment. Such structures, which would disturb the bedding, were not found. It is likely therefore that the larvae of some other insect genus is responsible, to judge from the tracks' shape, size and restriction to summer layers. Identification of the animal must await studies on the benthos of modern proglacial lakes.

Fossil animal tracks and traces have been found in proglacial lake sediments on several occasions. Schwarzbach (1938) describes insect

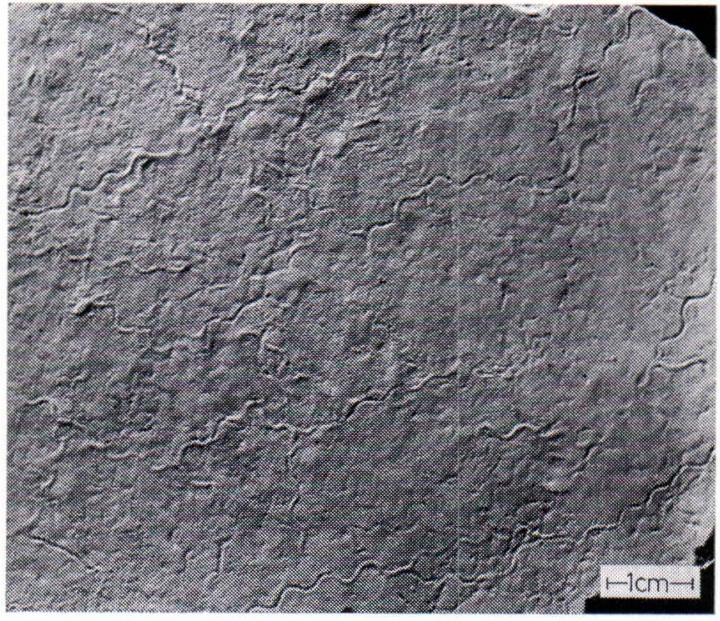

Fig. 5. Insect larval tracks in sediment of Glacial Lake Champagne, Alaska.

larval or crustacean trails from Germany, the latter closely resembling those found by Gibbard and Stuart (type a) and attributed to the Isopod Asellus. Other trails have been reported by Dahm and Otto (1953), Ludwig (1963) and Murawski (1964) from Germany; by Fliri, Hilscher and Markgraf (1971) from Austria, and by Gibbard and Stuart (1974) from England. Such traces seem therefore to be rather common given the appropriate conditions. Apparently fresh, fairly deep water with relatively fine grained sedimentation in spring and summer seems to be most suitable for animal life. How length of the summer ice-free season, water depth and lake chemistry control the diversity of the fauna is not clear. Proglacial lake waters are oxygenated throughout and have a continuous inwash of cold water in spring and summer. However, the large quantity of fine material in suspension means that primary food sources must be planktonic algae in the surface waters, aquatic plants in shallow water or inwashed plant material, although none are preserved.

To the authors' knowledge similar tracks have not been discovered in marine sediments. 


\section{Conclusions}

A section at Harassilta exposes $3.5 \mathrm{~m}$ of varved silty clay which can be correlated with the Baltic Ice Lake and Yoldia Sea sequences of Sauramo (1918). Two slump horizons dating from varve year +7 , probably derived from nearby high ground, are thought to record the fall in water level from BIII to YI. Trace fossils probably produced by benthonic insect larvae are found from the summer buff clayey silt horizons of the diatactic varves. The type is characteristic and is identical to trails found from similar proglacial lake environments in England, Sweden and Alaska. Although body fossils have been found in varved sediments, for example Fliri et al. (1971) and Sauramo (1928), they are relatively rare and it is highly unlikely that an insect larva would be preserved. However it is clear that benthonic organisms live in proglacial lakes even though they may not do so permanently. Further interpretation must await ecological studies on modern glacial lakes.

Acknowledgments - The author would like to thank Dr M. Saarnisto for his help and discussion of the stratigraphy of the site. The work was carried out whilst the author was in receipt of a Royal Society European Exchange Fellowship which is gratefully acknowledged.

\section{References}

Andersson, G. (1897) Den Centraljämska issjön. Sveriges Geol. Unders. Ser. C, 166: 1-38.

Dahm, D. and Otto, W. (1953) Lebensspuren in Bändertonen Nordwestdeutschlands. Freiberger Forsch. C5: $39-40$.

Donner, J. J. (1969) Land/Sea level changes in southern Finland during the formation of the Salpausselkä end moraines. Bull. Geol. Soc. Finland 41: 135-150.

Donner, J. J. (1971) Towards a stratigraphical division of the Finnish Quaternary. Commentat. Physico-Math. 41: 281-305.

Fliri, F., Hilscher, H. and Markgraf, V. (1971) Weitere Untersuchungen zur Chronologie der alpinen Vereisung (Bänderton von Baumkirchen, Inntal, Nordtirol). Z.f.Gletscherkd. und Glazialgeol. 7: 5-24.

Gibbard, P. L. and Stuart, A. J. (1974) Trace fos- sils from proglacial lake sediments. Boreas 3: $69-74$.

Ludwig, A. (1963) Ein neuer Fährtenfund aus dem Bänderton. Geologie 12: 493-496.

Murawski, H. (1964) Tierfährten aus dem Pleistozän von Holstein. Eiszeitalter u. GGW. 15: 44 -53 .

Sauramo, M. (1918) Geochronologische Studien über die spätglaziale Zeit in Südfinnland. Fennia 41: $1-44$.

Sauramo, M. (1925) Geochronologische Studien in Russland. Geol. Fören. Förh. 47: 521-522.

Sauramo, M. (1958) Die Geschichte der Ostsee. Ann. Acad. Scient. Fennicae Ser. AIII 51: 1522 .

Schwarzbach, M. (1938) Tierfährten aus eiszeitlichen Bändertonen. Z.f.Geschiebeforsch. u. Flachlandgeol. 14: 143-152.

Manuscript received, October 21, 1976 